\title{
Factors Affecting the Transmission and Spread of Sugarcane yellow leaf virus
}

\author{
S. Schenck, Hawaii Agriculture Research Center, Aiea, HI; and A. T. Lehrer, University of Bayreuth, Bayreuth, \\ Germany
}

\begin{abstract}
Schenck, S., and Lehrer, A. T. 2000. Factors affecting the transmission and spread of Sugarcane yellow leaf virus. Plant Dis. 84:1085-1088.

Sugarcane, Saccharum spp. hybrid, is widely infected in the United States and many other countries with a yellowing and stunting disease called sugarcane yellow leaf syndrome. The causal agent, Sugarcane yellow leaf virus (ScYLV), is a Polerovirus of the Luteoviridae family. In this study, it was transmitted by the sugarcane aphid, Melanaphis sacchari, and also by the corn leaf aphid, Rhopalosiphum maidis, and the rice root aphid, R. rufiabdominalis. Two other aphids that infest sugarcane in Hawaii did not transmit the virus. Some Hawaiian sugarcane cultivars are susceptible to ScYLV, while others remain virus-free in the field. The latter were not infected when inoculated with viruliferous $M$. sacchari. Virus-free plants of susceptible cultivars were produced through apical meristem culture and were readily reinfected by viruliferous $M$. sacchari. They were also quickly reinfected when planted in a field in proximity to other infected sugarcane naturally infested with $M$. sacchari. Sugarcane cultivars are hybrids of several Saccharum species. In a field-grown collection of Saccharum and related species, 11 to $71 \%$ of the clones of four of the species were infected with ScYLV. None of the related genus Erianthus plants were infected, but four clones were infected experimentally by aphid inoculation. A low to moderate percentage of corn, rice, and sorghum seedlings became infected when inoculated with ScYLV, but barley, oats, and wheat proved to be very susceptible. None of seven weeds common in sugarcane fields were infected with ScYLV.
\end{abstract}

Additional keywords: aphid vector, luteovirus

Severe leaf yellowing symptoms appeared in the $1980 \mathrm{~s}$ in fields of sugarcane, Saccharum spp. hybrid, cv. H 65-7052, on Oahu and the Hamakua coast of the island of Hawaii. The cause was unknown, and researchers failed to show any correlation between the yellowing and soil type, nutrition, mineral toxicity, or any other factor except drought stress. Symptoms continued to appear in various locations around the state on this variety, but other cultivars growing in close proximity appeared unaffected (22). Symptoms first appeared as bright yellowing of the abaxial surface of the midrib on the fourth or fifth youngest leaves. Leaf tip yellowing and necrosis followed and spread downward on the leaf blade until most leaves were bright yellow, sometimes with midrib reddening. This suggested possible disease of roots or the vascular system. Similar symptoms were reported from other sugarcane growing regions, including the West Indies (10), Florida, Texas (7), Australia (2), Mauritius (4), Réunion (19), Brazil (3), and South Africa (9). Brazil in particular reported significant yield reduction in some varieties (24). In

Corresponding author: S. Schenck

E-mail: sschenck@harc-hspa.com

Accepted for publication 22 June 2000.

Publication no. D-2000-0728-01R

(C) 2000 The American Phytopathological Society most regions, a virus was implicated, although the disease in Africa was shown to be associated with a phytoplasma (9).

This sugarcane virus is now considered to be a Polerovirus of the Luteoviridae family $(1,17)$ and was named Sugarcane yellow leaf virus (ScYLV). Luteoviridae, including ScYLV, have ssRNA genomes and often cause yellowing symptoms. They are limited to phloem tissue, are not mechanically transmitted (21), but are transmitted by aphids in a semipersistent manner (11). In sugarcane with yellow leaf syndrome (YLS), virus particles were observed in the cytoplasm of phloem companion cells (24), and tissue blot immunoassay (TBIA) also revealed that the sugarcane virus was associated with phloem (23). Vega et al. (24) tested antisera from the luteovirus Barley yellow dwarf virus (BYDV) serotypes PAV, MAV, RMV, SGV, and RPV for their serological reactions with the sugarcane virus. They reported a partial serological relationship between the sugarcane virus and BYDVPAV. Scagliusi and Lockhart (21) reported that BYDV-RPV antibodies detected proteins of virions purified from infected sugarcane. Recent findings have shown ScYLV to have the genome sequence organizational structure of a Polerovirus (formerly BYDV subgroup II) (17).

Sugarcane yellow leaf syndrome is spread in vegetative planting material and is not eliminated by the hot water dip treatment used to rid sugarcane planting material (setts) of bacterial or fungal pathogens (22). Since the entire state production of variety $\mathrm{H}$ 65-7052 was suspected of being infected, and since sugarcane is vegetatively propagated, it was impossible to compare diseased with healthy plants. A second cultivar, $\mathrm{H}$ 736110, unexpectedly suffered extensive stalk death and loss of sucrose yield when irrigation was withheld during plantation preharvest ripening. This cultivar had not previously shown yellowing symptoms but was subsequently shown to be infected with ScYLV.

Diagnostic procedures for detection of ScYLV infection have been developed $(6,8,14,23)$. Antiserum specific to ScYLV prepared from purified virus (21) has now been employed successfully with samples from many locations to detect ScYLV using both enzyme-liked immunosorbent assay (ELISA) $(6,8)$ and TBIA (23). Using TBIA, surveys of Hawaiian plantations for ScYLV were carried out in 1997 through 1999 to determine the extent of infection (23). The virus was found to be more widespread than previously thought, since most of the infected cultivars were symptomless.

The objectives of this research were to determine host range and possible alternate sources of viral infection, determine the vector aphid species, continue field testing of resistance in Hawaiian varieties, and determine the rate and pattern of ScYLV spread in the field.

\section{MATERIALS AND METHODS}

Virus-free sugarcane. We produced virus-free plants of the sugarcane cultivars known to be susceptible to ScYLV by means of tissue culture (25). Shoot tips or lateral bud tips 0.3 to $0.7 \mathrm{~mm}$ in diameter were excised and placed on Murashige and Skoog's medium (18) containing $1 \mathrm{mg}$ of 2,4-D per milliliter until vigorous callus tissue developed. Plants were subsequently regenerated on Murashige and Skoog's medium without delay in order to minimize somaclonal variation. A higher survival rate was obtained with buds than with shoots (M. Fitch, A. T. Lehrer, S. Schenck, and P. H. Moore, unpublished data).

Virus-free plants of ScYLV-susceptible sugarcane cultivars H 65-7052, H 73-6110, and $\mathrm{H}$ 87-4094 were produced. Cultivar $\mathrm{H}$ 78-4094 has now been maintained virusfree since 1998 in the greenhouse and repropagated several times. A field planting for use as a source of virus-free material is being maintained in a location remote from 
other sugarcane. Plants used for transmission studies were reassayed for ScYLV prior to their use as test plants. No test plant was used in more than one transmission study.

Resistance in commercial sugarcane cultivars. In Hawaiian plantations, virus-

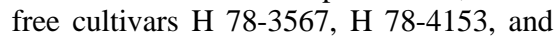

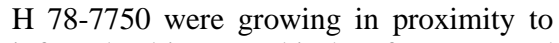
infected cultivars, and it therefore appeared they might be genetically resistant to ScYLV. This was tested by inoculating 16 potted plants of each virus-free cultivar with $M$. sacchari aphids. Inoculated plants were kept for 3 to 6 months and assayed three times by TBIA. Plants of the susceptible varieties, $\mathrm{H}$ 73-6110 and $\mathrm{H}$ 87-4094, which were regenerated from virus-free meristem cultures, were also inoculated and subsequently tested for ScYLV.

Alternate host plants. Hawaii Agriculture Research Center maintains a collection of commercial sugarcane cultivars (Saccharum spp. hybrids) as well as numerous related species-S. officinarum, S. spontaneum, S. robustum, $S$. sinensis, and Erianthus spp.--from around the world. Many of the field plots were assayed for ScYLV infection.

Some cereal crop plants were tested for susceptibility to ScYLV by inoculating potted plants with the viruliferous aphid vector. The gramineous hosts inoculated were: corn (Zea mays 'Supersweet \#10A'), rice (Oryza sativa), wheat (Triticum aestivum 'Norstar' and 'Bobwhite'), oats (Avena sativa 'Coker 227'), barley (Hordeum vulgare), and sorghum (Sorghum vulgare $\times S$. vulgare var. sudanense 'Sudax').

A preliminary survey was made for ScYLV infection in weed species commonly found in sugarcane fields. The species tested were swollen fingergrass (Chloris barbata), purple nutsedge (Cyperus rotundus), sandbur (Cenchrus echinatus), yellow foxtail (Setaria glauca), Hilo grass (Paspalum conjugatum), fuzzy rattlepod (Crotalaria incana), and Guinea grass (Panicum maximum).

TBIA. ScYLV detection in plant tissue samples was performed with the tissue blot immunoassay (TBIA) following the method of Schenck et al. (23). Sugarcane plants were assayed with tissue blots of cross-sectioned leaf blade midribs and sometimes also shoot growing points and

Table 1. Survey of Saccharum spp. and related genera for Sugarcane yellow leaf virus infection in Hawaii

\begin{tabular}{lcc}
\hline Host species & $\begin{array}{c}\text { Clones } \\
\text { infected/tested }\end{array}$ & $\begin{array}{c}\text { \% clones } \\
\text { infected }\end{array}$ \\
\hline S. officinarum & $13 / 25$ & 52 \\
S. robustum & $2 / 18$ & 11 \\
S. spontaneum & $3 / 14$ & 21 \\
S. sinensis & $5 / 7$ & 71 \\
Miscanthus & $0 / 3$ & 0 \\
$\quad$ hybrid & $0 / 19$ & 0 \\
Erianthus spp. & & \\
\hline
\end{tabular}

roots. Large, field-grown plants and young container-grown plants were treated in the same manner. Because of their small size, other gramineous crop plants were usually assayed from cross sections of stems rather than leaves.

Aphid colonies. The species tested for their ability to transmit ScYLV were: Melanaphis sacchari, the sugarcane aphid, Sipha flava, the yellow sugarcane aphid, Rhopalosiphum maidis, the corn leaf aphid, $R$. rufiabdominalis, the rice root aphid, and Hysteroneura setariae, the rusty plum aphid. They were collected from fields of sugarcane, corn, and rice. Identification was based on Blackman and Eastop (5). These aphid species were able to feed and multiply on sugarcane, although sugarcane was not the preferred host in all cases. Therefore, depending on species feeding preference, aphids were reared on sugarcane, corn, barley, or rice plants growing in pots within insect cages. The rice root aphids were reared on rice seedlings growing in clear plastic Magenta boxes by a modified method of Ridland et al. (20). Colonies were frequently restarted because the tiny parasitoid wasp, Diaretriella rapae, was able to enter the cages and decimate the aphid populations.

Virus transmission. Viruliferous aphids for transmission studies were either reared on sugarcane plants already infected with ScYLV or transferred to the infected plants for $48 \mathrm{~h}$ prior to using them to transmit virus to uninfected plants. Apterous aphids were transferred one by one from plant to plant using a small watercolor brush. Depending on the test plant size and the available number of aphids, between 4 and 100 aphids were transferred per plant. Aphids were allowed to feed on the new plants for at least 3 days before they were removed, and the plants were placed in insect-proof cages to prevent further aphid infestation. Sugarcane plants were grown for 2 to 3 weeks before a leaf was assayed for virus. Additional leaves were tested over a period of 2 to 6 months. Small, gramineous seedlings were assayed once at 4 to 6 weeks after inoculation.

Field study of symptom expression. Field studies were undertaken to determine the effects of various environments on symptom expression of several cultivars. To follow symptom expression of the 10 most important Hawaiian cultivars, test plots were established on Kauai (three locations), Maui (three locations), and Oahu (two locations). Cultivars planted were: H 65-7052, H 73-6110, H 78-3567, H 78-3606, H 78-4153, H 78-7750, H 823569, H 87-4094, and H 87-4319. Stalk pieces (setts) for planting were approximately $45 \mathrm{~cm}$ in length and were treated following standard plantation practice (30min hot water treatment at $50^{\circ} \mathrm{C}$ followed by propiconazole fungicide dip). Each cultivar was planted in three replicate plots, $3 \mathrm{~m}$ in length, in each location in a randomized pattern. Each replicate plot was planted with eight setts. A single sett generally has three buds (eyes), of which one or two germinate. Infection was determined by sampling one leaf per replicate plot and testing by means of TBIA. After germination, virus infection and symptom expression were monitored at 6-week intervals for up to 14 months.

Natural virus spread. Observations of the pattern of reinfection in virus-free plants of a susceptible cultivar, H 87-4094, under natural field conditions was carried out on Oahu. A single row of virus-free $\mathrm{H}$ 87-4094 was planted $1 \mathrm{~m}$ from a row of infected H 87-4094, following the same planting protocol as above. The plot was adjacent to an area of infected sugarcane infested with the sugarcane aphid, $M$. sacchari. Samples were also taken from the second planting of virus-free H 87-4094, which was located far from any infected sugarcane. Samples of the youngest, fully unfolded leaves were taken at 6-week intervals from both plots and tested for virus infection.

\section{RESULTS}

Resistance in commercial sugarcane cultivars. Hawaiian sugarcane cultivars that were virus-free in plantation fields were tested for resistance to infection. None of the aphid-inoculated plants of $\mathrm{H}$ 78-3567, H 78-4153, and $\mathrm{H} \mathrm{78-7750} \mathrm{tested}$ positive for ScYLV. All of the virus-free plants of susceptible cultivars H 73-6110 and $\mathrm{H}$ 87-4094 became reinfected. It was concluded that some commercial sugarcane cultivars are resistant to ScYLV infection.

Alternate hosts of ScYLV. There were a number of $S$. officinarum clones in field plots that were naturally infected with ScYLV, and that species seems to be generally susceptible (Table 1). Other Sac-

Table 2. Infection of gramineous seedlings with Sugarcane yellow leaf virus by inoculation with Melanaphis sacchari aphids

\begin{tabular}{lccc}
\hline Test plant & Seedlings tested & Aphids per plant & \% plants infected \\
\hline Wheat & 57 & 18 & 96.5 \\
Wheat (check) & 20 & 0 & 0 \\
Oats & 37 & 18 & 94.6 \\
Oats (check) & 8 & 0 & 0 \\
Barley & 63 & 18 & 93.7 \\
Barley (check) & 19 & 0 & 0 \\
Rice & 59 & 8 & 8.5 \\
Corn & 19 & 30 & 10.5 \\
\hline
\end{tabular}


charum species, $S$. spontaneum, $S$. robustum, and $S$. sinensis, also had some infected clones. Nineteen clones of Erianthus spp. were uninfected in field plots, but when potted plants were inoculated, four of the clones became infected. None of the species related to commercial sugarcane are completely resistant to ScYLV, although some of the clones of each may be resistant.

The corn and rice seedlings were not very susceptible to ScYLV, sorghum was moderately so, and wheat, oats, and barley were very susceptible (Table 2). Uninoculated seedlings of wheat, oats, and barley gave negative reactions to TBIA for ScYLV. In our preliminary survey of weeds in Hawaiian sugarcane fields, we did not find any that were infected.

Aphid vectors of ScYLV. We consistently and routinely transmitted ScYLV with Melanaphis sacchari. In one trial, 9 sugarcane plants were inoculated with only 10 M. sacchari individuals each and 8 of the plants became infected with ScYLV. Virus was detected in leaves, roots, and growing points of the inoculated plants. In another test, a single $M$. sacchari was placed on each of 34 wheat seedlings. After 4 weeks, 25 of the 34 seedlings (73.5\%) tested positive for ScYLV.

The corn leaf aphid, Rhopalosiphum maidis, is common on corn in Hawaii and will occasionally infest sugarcane. In our trials, $R$. maidis transmitted ScYLV to a lower percentage of inoculated plants than did M. sacchari. When 14 virus-free sugarcane plants were inoculated with $100 R$. maidis each, only one of the plants eventually tested positive for the virus. Since sugarcane is not a preferred host of $R$. maidis, this species was also assayed on wheat. While $M$. sacchari transmitted ScYLV to $96 \%$ of wheat seedlings, $R$. maidis infected only $20 \%$, and these had only a low number of positive phloem bundles in each tissue blot.

In Hawaii, there are other aphid species that sometimes feed and multiply on sug- arcane. These were tested for their ability to transmit ScYLV from virus-infected $\mathrm{H}$ 73-6110 to susceptible, virus-free sugarcane plants growing in pots. The yellow sugarcane aphid, Sipha flava, is common in Hawaii. A total of 14 virus-free, susceptible sugarcane plants were inoculated with $60 \mathrm{~S}$. flava each, but none became infected with ScYLV. This species is damaging to sugarcane and causes necrosis of the leaves it feeds on, which might inhibit further replication of any virus present.

In preliminary trials, the rice root aphid, Rhopalosiphum rufiabdominalis, transmitted ScYLV from infected wheat seedlings to wheat and oats. Further trials with sugarcane are underway. The rusty plum aphid, Hysteroneura setariae, failed to transmit ScYLV to any of the eight sugarcane plants that were inoculated with $60 \mathrm{H}$. setariae each.

Infection and symptom expression in Hawaiian cultivars. Ten Hawaiian sugarcane cultivars planted in field plots in several locations became infected with ScYLV in a pattern consistent with prior plantation field surveys (Table 3). Cultivars $\mathrm{H} \mathrm{78-}$ 4153, H 78-7750, $\mathrm{H} \mathrm{87-4319,} \mathrm{and} \mathrm{H}$ 823569 remained virus-free for the duration of the experiment. H 73-6110, H 87-4094, and $\mathrm{H}$ 78-3606 were infected. H65-7052, H77-4643, and H78-3567 gave variable reactions. The latter three cultivars continued to be infected with ScYLV, but the TBIA results were sometimes positive and sometimes negative. This may have been because the virus titer was low or variable and was sometimes below the level of detection with this diagnostic procedure. Symptom expression in the infected plants was more pronounced during the cooler winter months at all locations. Symptoms also often appeared as plants aged or when they suffered from drought stress. However, there was no single environmental factor that could be correlated with YLS symptom expression in all instances. Symptomatic plants occasionally produced new, vigorous growth that was free of YLS yellowing.
There were also cultivar differences in YLS symptom expression. In one test location, leaf yellowing appeared on $\mathrm{H}$ 6570524 months after planting, whereas cultivar H 73-6110 did not show yellowing until 10 months of age. Among the infected cultivars, H 65-7052 frequently showed severe yellowing symptoms. By contrast, H 78-3606 was never seen to have YLS even though it consistently tested positive by TBIA. H 73-6110 showed symptoms at a later stage of development than did H 65-7052, and only when water stressed. H 87-4094 became symptomatic at about the same age and under the same conditions as H73-6110, but its symptoms were always less severe.

Reinfection of susceptible sugarcane in field plots. Nearly half of ScYLV-free H 87-4094 stools growing near infected sugarcane and infested with aphids became reinfected within 18 weeks (Table 4). In comparison, the plots of $\mathrm{H}$ 87-4094 located far from any other sugarcane still remained uninfected 12 months after planting.

\section{DISCUSSION}

Each Luteoviridae species is transmitted by only one or a few species of aphid (16). Lockhart et al. (14) and Scagliusi and Lockhart (21) reported transmission of ScYLV with the sugarcane aphid, Melanaphis sacchari, and the corn leaf aphid, Rhopalosiphum maidis. The most important and efficient vector of ScYLV in Hawaii is $M$. sacchari, which is common in sugarcane fields. Field plantings of sus-

Table 4. Reinfection of Sugarcane yellow leaf virus (ScYLV)-free H 87-4094 under natural field conditions in Hawaii

\begin{tabular}{ccc}
\hline $\begin{array}{l}\text { Plant age } \\
\text { (weeks) }\end{array}$ & $\begin{array}{c}\text { ScYLV-positive } \\
\text { plants/total tested }\end{array}$ & $\begin{array}{c}\text { \% infected } \\
\text { plants }\end{array}$ \\
\hline 0 & $0 / 6$ & 0 \\
6 & $0 / 6$ & 0 \\
11 & $1 / 6$ & 17 \\
18 & $12 / 26$ & 46 \\
24 & $9 / 25$ & 36 \\
\hline
\end{tabular}

Table 3. Sugarcane yellow leaf virus infection of 9 commercial Hawaiian sugarcane varieties in field plots over a 1-year period ${ }^{\mathrm{a}}$

\begin{tabular}{|c|c|c|c|c|c|c|c|c|c|}
\hline \multirow{2}{*}{$\begin{array}{l}\text { Plant age } \\
\text { (weeks) }\end{array}$} & \multicolumn{9}{|c|}{ Cultivar } \\
\hline & H 78-3567 & H 78-4153 & H 78-7750 & H 65-7052 & H 73-6110 & H 87-4094 & H 78-3606 & H 87-4319 & H 82-3569 \\
\hline 0 & $0^{\mathrm{b}}$ & 0 & 0 & 0 & 100 & 100 & 100 & 0 & 0 \\
\hline 6 & 7 & 0 & 0 & 0 & 100 & 79 & 92 & 0 & 0 \\
\hline 13 & 13 & 0 & 0 & 0 & 96 & 88 & 88 & 0 & 0 \\
\hline 19 & 8 & 0 & 0 & 21 & 100 & 100 & 100 & 0 & 0 \\
\hline 26 & 4 & 0 & 0 & 25 & 96 & 96 & 96 & 0 & 0 \\
\hline 32 & 4 & 0 & 0 & 8 & 88 & 79 & 88 & 0 & 0 \\
\hline 39 & 4 & 0 & 0 & 38 & 88 & 79 & 91 & 0 & 0 \\
\hline 45 & 0 & 0 & 0 & 8 & 100 & 92 & 100 & 0 & 0 \\
\hline 52 & 0 & 0 & 0 & 0 & 93 & 93 & 87 & 0 & 0 \\
\hline 58 & 0 & 0 & 0 & 13 & 100 & 77 & 93 & 0 & 0 \\
\hline 65 & 0 & 0 & 0 & 0 & 93 & 93 & 87 & 0 & 0 \\
\hline Total $^{\mathrm{c}}$ & $11 / 191$ & $0 / 189$ & $0 / 178$ & $30 / 189$ & $181 / 190$ & $167 / 189$ & $171 / 186$ & $0 / 189$ & $0 / 190$ \\
\hline$\%$ positive & $6 \%$ & $0 \%$ & $0 \%$ & $16 \%$ & $95 \%$ & $88 \%$ & $92 \%$ & $0 \%$ & $0 \%$ \\
\hline
\end{tabular}

${ }^{a}$ Data presented are an average of eight field trials with three replicate plots of each cultivar in each trial.

${ }^{\mathrm{b}}$ Percentage of plants tested giving positive reaction with tissue blot immunoassay.

${ }^{c}$ Number of positive reactions per total number of tested plants. 
ceptible, ScYLV-free plants rapidly became reinfected when infested with aphids from nearby infected sugarcane. Although Sipha flava is also common in Hawaii and multiplies to high populations on sugarcane, it did not transmit ScYLV in any of our trials. ScYLV was also transmitted by $R$. maidis and $R$. rufiabdominalis, but these aphid species do not infest sugarcane as frequently as does $M$. sacchari.

We have confirmed the existence of ScYLV-resistant Hawaiian cultivars, and preliminary research (S. Schenck, unpublished) indicates that resistance is inherited. Breeding and production of ScYLVresistant cultivars may therefore prove useful. Preventing virus spread by controlling the aphids is not practical, since insecticides are not used on sugarcane in Hawaii. It is also possible to produce virusfree plants of susceptible sugarcane cultivars and to multiply them rapidly by means of micropropagation. However, this is costly, and unless they could be planted in fields far from a source of ScYLV, they would soon become reinfected.

Species related to commercial Saccharum spp. cultivars are susceptible to ScYLV, but are not planted near commercial plantations and do not pose a threat as an alternate source of infection. Barley, oats, and wheat were very susceptible to ScYLV, but since these are reseeded for each crop and since Luteoviridae are not known to be seed transmitted (11), these crops are not likely to be a virus source for sugarcane infection. However, these cereals could become infected in the field by viruliferous $M$. sacchari or $R$. maidis from neighboring sugarcane. It is unknown what effect ScYLV infections might have on cereal crop yields.

The effects of ScYLV on growth and yield in Hawaiian sugarcane have not yet been quantified. Studies are underway comparing yields of virus-free and infected plots of susceptible cultivars. Research with phloem-limited viruses of other crops and observations of sugarcane indicate that sucrose transport is affected and growth is slowed even when no YLS symptoms are evident $(12,15)$. Higher than normal concentrations of soluble solids and sucrose were measured in juice expressed from sugarcane leaves with $\operatorname{ScYLV}(6,13)$. This was presumably due to an inability of the phloem to translocate sucrose out of the leaves. These observations may help explain the severe effects of stress conditions on ScYLV-infected sugarcane.

Currently, no control measures for ScYLV are practiced in Hawaii. This research has identified possible virus sources and vectors in plantations and has demonstrated the existence of resistant sugarcane cultivars. Continuing work to evaluate yield reduction and the effects of stress on infected cultivars will indicate whether breeding for resistance or producing virusfree, susceptible cultivars will be worth the costs involved.

\section{ACKNOWLEDGMENTS}

We thank M. Fitch for assistance with meristem culture procedures, B. E. Lockhart for supplying ScYLV antiserum, and A. Ota for advice and suggestions on aphid identification and rearing. This work was supported in part by a U.S. Department of Agriculture Agricultural Research Service cooperative agreement (CA 58-5320-3-460) with the Hawaii Agriculture Research Center and in part by the Deutsche Forschungsgemeinschaft DFG (KO 553/24-1).

\section{LITERATURE CITED}

1. Allen, E., Wang, S., and Miller, W. A. 1999. Barley yellow dwarf virus RNA requires a cap-independent translation sequence because it lacks a 5' cap. Virology 253:139-144.

2. Anonymous. 1994. Yellow leaf syndrome may be in Australia. Bureau of Sugar Experiment Stations (BSES) Bull. 48:14-15.

3. Anonymous. 1995. Yellow leaf syndrome (YLS). Centro de Tecnologia Copersucar, Brasil, Annu. Rep. 1994/1995:20.

4. Anonymous. 1996. Yellow leaf syndrome. Mauritius Sugar Industry Res. Inst. Annu. Rep. 1996:35.

5. Blackman, R. L., and Eastop, V. R. 1984. Aphids on the World's Crops: An Identification Guide. John Wiley \& Sons, New York.

6. Comstock, J. C., Irey, M. S., Lockhart, B. E., and Wang, Z. K. 1998. Incidence of yellow leaf syndrome in CP cultivars based on polymerase chain reaction and serological techniques. Sugar Cane 1998(4):21-24.

7. Comstock, J. C., Irvine, J. E., and Miller, J. D. 1994. Yellow leaf syndrome appears on the United States mainland. Sugar J. 1994(March):33-35.

8. Comstock, J. C., Wang, Z. K., Miller, J. D., Irey, M. S., and Lockhart, B. E. L. 1998. Widespread occurrence of yellow leaf syndrome in sugarcane clones at Canal Point, Florida. J. ASSCT 18:45.

9. Cronjé, C. P. R., Tymon, A. M., Jones, P., and Bailey, R. A. 1998. Association of a phytoplasma with yellow leaf syndrome of sugarcane in Africa. Ann. Appl. Biol. 133:177-186.

10. Daugrois, J. H., Jean-Baptiste, I., Lockhart, B. E. L., Irey, M. S., Chatenet, M., and Rott, P. 1999. First report of sugarcane yellow leaf vi- rus in the French West Indies. Plant Dis. 83:588

11. Francki, R. I. B., Milne, R. G., and Hatta, T. 1985. Luteovirus group. Pages 137-141 in: Atlas of Plant Viruses, Vol. I. CRC Press, Boca Raton, FL.

12. Jensen, S. G. 1969. Photosynthesis, respiration, and other physiological relationships in barley infected with barley yellow dwarf virus. Phytopathology 58:204-208.

13. Legendre, B. L., Clarke, M. A., Godshall, M. A., and Grisham, M. P. 1999. Developments in sugarcane agriculture that affect processing. Zuckerindustrie 124:120-125.

14. Lockhart, B. E. L., Irey, M. J., and Comstock, J. S. 1996. Sugarcane bacilliform virus, sugarcane mild mosaic virus and sugarcane yellow leaf syndrome. Pages 108-112 in: Sugarcane Germplasm Conservation and Exchange. B. J. Croft, C. M. Piggin, E. S. Wallis, and D. M. Hogarth, eds. Australian Centre for International Agricultural Research, Canberra Proc. No. 67.

15. Matthews, R. E. F. 1991. Plant Virology, 3rd ed. Academic Press, New York. pp. 439-440.

16. Miller, W. A., and Rosochová, L. 1997. Barley yellow dwarf viruses. Annu. Rev. Phytopathol. 35:167-190.

17. Moonan, F., Molina, J., and Mirkov, T. E. 2000. Sugarcane yellow leaf virus: An emerging virus that has evolved by recombination between luteovirus and polerovirus ancestors. Virology 269:156-171.

18. Murashige, T., and Skoog, F. 1962. A revised medium for rapid growth and bioassays with tobacco tissue cultures. Physiol. Plant. 15:473-497.

19. Rassaby, L., Girard, J. C., Irey, M. S., Lockhart, B. E. L., and Rott, P. 1999. Survey of sugarcane yellow leaf syndrome in Réunion Island. Sugar Cane Intl. 1999(Oct.): 18.

20. Ridland, P. M., Sward, R. J., and Tomkins, R. B. 1988. A simple rearing system for cereal aphids, especially suited to transmission studies with barley yellow dwarf virus. Australas. Plant Pathol. 17:17-19.

21. Scagliusi, S. M., and Lockhart, B. E. L. 2000. Transmission, characterization, and serology of a luteovirus associated with yellow leaf syndrome of sugarcane. Phytopathology 90:120-124.

22. Schenck, S. 1990. Yellow leaf syndrome - a new sugarcane disease. Page 38 in: Exp. Stn. Hawaiian Sugar Planters' Assn. Annu. Rep.

23. Schenck, S., Hu, J. S., and Lockhart, B. E. 1997. Use of a tissue blot immunoassay to determine the distribution of sugarcane yellowleaf virus in Hawaii. Sugar Cane 1997(4):5-8.

24. Vega, J., Scagliusi, S. M. M., and Ulian, E. C. 1997. Sugarcane yellow leaf disease in Brazil: Evidence of association with a luteovirus. Plant Dis. 81:21-26.

25. Wagih, M. E., Gordon, G. H., Ryan, C. C., and Adkins, S. W. 1995. Development of an axillary bud culture technique for Fiji disease virus elimination in sugarcane. Aust. J. Bot. 43:135-143. 